\title{
A New Analytical Q-Absorbance Ratio Method Development and Validation for Simultaneous Estimation of Lamivudine and Isoniazid
}

\author{
Gitu Pandey and Brahmeshwar Mishra \\ Department of Pharmaceutics, Indian Institute of Technology (Banaras Hindu University), Varanasi Uttar Pradesh 221005, India \\ Correspondence should be addressed to Brahmeshwar Mishra; bmishrabhu@rediffmail.com
}

Received 27 August 2013; Accepted 17 November 2013

Academic Editors: D. Chattopadhyay, A. A. Ensafi, B. Kiran, R. Schneider, and A. Toncelli

Copyright (C) 2013 G. Pandey and B. Mishra. This is an open access article distributed under the Creative Commons Attribution License, which permits unrestricted use, distribution, and reproduction in any medium, provided the original work is properly cited.

\begin{abstract}
A new UV spectrophotometric absorption ratio method was developed and validated for the simultaneous estimation of lamivudine and isoniazid. The method involved $Q$-absorption ratio analysis using two wavelengths, with one being the $\lambda_{\max }$ of lamivudine $\left(272 \mathrm{~nm}, \lambda_{2}\right)$ and the other being the isoabsorptive point of both drugs $\left(246 \mathrm{~nm}, \lambda_{1}\right)$. Beer's law was obeyed in the concentration range between 5 and $30 \mu \mathrm{g} / \mathrm{mL}$ for both lamivudine and isoniazid. The results of analysis have been validated statistically and by recovery studies as per ICH guidelines. The accuracy ranged between 99.65 and $101.91 \%$ and Sandell's sensitivity ranged between 0.0229 and $0.0347 \mu \mathrm{g} / \mathrm{cm}^{2}$. The method was found to be simple, precise, reproducible, rapid, and economical. Hence, it could be used in the analysis of laboratory samples and marketed formulations containing these two drugs in the future.
\end{abstract}

\section{Introduction}

A recent WHO report on tuberculosis (TB) in 2012 has shown that there were an estimated 8.7 million incident cases of TB in 2011 (13\% coinfected with HIV). There were also 1.4 million deaths from TB, 990,000 deaths among HIV-negative individuals and 430,000 among people who were HIV-positive [1]. Many TB carriers who are infected with HIV are 30 to 50 times more likely to develop active TB than those without HIV [2]. HIV infected individuals are not only at a greater risk for acquiring $\mathrm{TB}$ but also reactivation of latent $\mathrm{TB}$ infection is greatly increased due to the fact that the very cells that hold the latent $\mathrm{TB}$ in check (the CD4+ T lymphocytes) are precisely the cells that are rendered dysfunctional in HIV-infected individuals. There are evidences to believe that the main factor for the resurgence of $\mathrm{TB}$ has been the human immunodeficiency virus (HIV) [3]. Lamivudine (LAM), a leading antiretroviral drug, also known as 3TC, is chemically $2(1 H)$-pyrimidinone, 4-amino-1-[2-(hydroxymethyl)-1, 3-oxathiolan-5-yl]-, (2Rcis) (Figure 1) with molecular formula $\mathrm{C}_{8} \mathrm{H}_{11} \mathrm{~N}_{3} \mathrm{O}_{3} \mathrm{~S}$ and molecular weight 229.26 [4]. This deoxycytidine analogue is phosphorylated intracellularly and inhibits HIV reverse transcriptase as well as hepatitis B virus DNA polymerase. Most human DNA polymerases are not affected and systemic toxicity of 3TC is low [5]. Isoniazid (INH), a first line antitubercular, is chemically 4 -pyridinecarboxylic acid hydrazide or isonicotinic acid hydrazide (Figure 2), having molecular formula $\mathrm{C}_{6} \mathrm{H}_{7} \mathrm{~N}_{3} \mathrm{O}$ and molecular weight 137.14 [4]. It acts by inhibiting the synthesis of mycolic acids which get attached to arabinogalactan to form part of mycobacterial cell wall. It is an essential component of all antitubercular regimens, unless the patient is not able to tolerate it or bacilli are resistant $[5,6]$. The simultaneous analysis of these two drugs INH and LAM is highly desirable as this will allow more efficient clinical data generation in the patients who are coinfected with tuberculosis and AIDS and for quantitative estimation of these drugs in combination formulations which may be marketed in the future. The absorbance ratio method is a method for simultaneous estimation of two components depending upon the property that the ratio of absorbances at any two wavelengths is a constant value independent of concentration or pathlength $[7,8]$. An extensive and intensive literature survey has revealed that there is no 
<smiles>Nc1ccn(C2CSC(CO)O2)c(=O)n1</smiles>

FIGURE 1: Structure of lamivudine.<smiles>NNC(=O)c1ccncc1</smiles>

FIgURE 2: Structure of isoniazid.

absorption ratio method for simultaneous analysis of LAM and INH in pharmaceutical preparations. However it has been used for simultaneous analysis of prednisolone and 5 -amino salicylic acid, valsartan, and hydrochlorothiazide, metformin hydrochloride, and fenofibrate [9-11]. The present work describes a simple, accurate, and precise absorption ratio method for simultaneous determination of these two drugs. The method was validated as per the current $\mathrm{ICH}$ guidelines [12-14].

\section{Materials and Methods}

2.1. Reagents and Apparatus. Lamivudine and isoniazid were obtained as gift samples from Mylan Laboratories, Nashik, Maharashtra, India, and Lupin Pharma Ltd., Pune, Maharashtra, India, respectively. All other chemicals used were of analytical grade. A double beam UV-Visible spectrophotometer, model 1700, Shimadzu, Japan, with software UV Probe 2.10 and $1 \mathrm{~cm}$ quartz cell, was used for all analysis.

2.2. Preparation of Standard Stock Solutions. Standard stock solution $(1000 \mu \mathrm{g} / \mathrm{mL})$ of LAM and INH was prepared separately by dissolving carefully weighed $100 \mathrm{mg}$ of drug in $100 \mathrm{~mL}$ volumetric flask and diluting up to the mark with phosphate buffer ( $\mathrm{pH}$ 7.4). Ten $\mathrm{mL}$ of this solution was diluted up to $100 \mathrm{~mL}$ with phosphate buffer ( $\mathrm{pH}$ 7.4) to get working stock solution $(100 \mu \mathrm{g} / \mathrm{mL})$.

2.3. Determination of Isoabsorptive Point and Wavelength of Maximum Absorbance $\left(\lambda_{\max }\right)$. Solutions of $10 \mu \mathrm{g} / \mathrm{mL}$ of both drugs were prepared from working stock solution and scanned in the range of $200 \mathrm{~nm}$ to $400 \mathrm{~nm}$ against phosphate buffer ( $\mathrm{pH}$ 7.4) as blank. The overlaying spectrum was also obtained to determine isoabsorptive point.

2.4. Preparation of Sample Solutions from Standard Stock Solution. The sample solutions of various concentrations were prepared from the standard stock solution by diluting aliquots of working stock solutions appropriately.

2.5. Calibration Curve (Linearity). A calibration curve was plotted over a concentration range of $5-30 \mu \mathrm{g} / \mathrm{mL}$ for both LAM and INH. Accurately measured working stock solution of $\operatorname{LAM}(2.5,5.0,7.5,10.0,12.5$, and $15.0 \mathrm{~mL})$ and working stock solution of INH $(2.5,5.0,7.5,10.0,12.5$, and $15.0 \mathrm{~mL})$ were transferred to two separate series of $50 \mathrm{~mL}$ volumetric flask and diluted up to the mark with phosphate buffer $(\mathrm{pH}$ 7.4). The absorbance of both solutions was taken at their respective $\lambda_{\max }$ and at isoabsorptive point. The calibration curves were constructed by plotting concentration against absorbance where each reading was an average of three determinations.

2.6. Application of the Proposed Method for Estimation in Standard Laboratory Mixture. The absorptivity coefficient of both drugs was determined and the individual concentration of LAM and INH was determined using the following equations:

$$
\begin{array}{r}
C_{\mathrm{INH}}=\frac{Q_{M}-Q_{Y}}{Q_{X}-Q_{Y}} \times \frac{A_{1}}{a_{X 1}}, \\
C_{\mathrm{LAM}}=\frac{Q_{M}-Q_{X}}{Q_{Y}-Q_{X}} \times \frac{A_{1}}{a_{Y 1}},
\end{array}
$$

where $Q_{M}=A_{2} / A_{1}, Q_{X}=a_{X 2} / a_{X 1}$, and $Q_{Y}=a_{Y 2} / a_{Y 1} ; A_{1}$ and $A_{2}$ are the absorbance, of the mixture at $246 \mathrm{~nm}$ and $272 \mathrm{~nm}$, respectively; $a_{X 1}$ and $a_{Y 1}$ are absorptivities of INH and LAM, respectively, at $246 \mathrm{~nm} ; a_{X 2}$ and $a_{Y 2}$ are absorptivities of INH and LAM, respectively, at $272 \mathrm{~nm}$.

\section{Method Validation}

3.1. Linearity and Range. Linearity, consisting of the basic elements input $\rightarrow$ converter $\rightarrow$ output, is the assumption that there is a straight line relationship between the input $(x)$ and output $(y)$ variables that can be written mathematically by the expression $y=f(x)$ if the straight line crosses through the origin or by the expression $y=f(x)+\delta$ if the straight line does not cross through the origin. The linear range corresponds to the valid interval of functional dependence of the signal on concentration or mass which assumes homoscedasticity of the measurements over the linear range. The linear response of LAM and INH was determined by analyzing five independent levels of the calibration curve in the range of $5-30 \mu \mathrm{g} / \mathrm{mL}$.

3.2. Precision. The term precision is defined by the ISO International Vocabulary of Basic and General Terms in Metrology (ISO-VIM) and ICH as the closeness of agreement between quantity values obtained by replicate measurements of a quantity under specified conditions [11]. Assessing the precision implies expressing numerically the random error or the degree of dispersion of a set of individual measurements by means of the standard deviation, the variance, or the coefficient of variation. 
3.3. Repeatability (Within-Run Precision). It is the concordance of a series of measurements of the same quantity when the experiments are conducted under same conditions (analyst, apparatus, instrument, and day) in a rapid succession. For this experiment, standard solution of LAM and INH $(15+15 \mu \mathrm{g} / \mathrm{mL})$ was prepared and analyzed six times as per the proposed method.

3.4. Intermediate Precision (Between-Run Precision). It is the concordance of a series of measurements of the same quantity when the experiments are conducted within the same laboratory under different conditions (analyst, apparatus, instrument, and day). Standard solution of LAM and INH $(15+15 \mu \mathrm{g} / \mathrm{mL})$ was prepared and analyzed as per the proposed method.

3.5. Accuracy (\% Recovery). The accuracy of an analytical procedure expresses the closeness of agreement between the value which is accepted either as a conventional true value or an accepted reference value and the value found. The recovery experiments were carried out in triplicate by spiking previously analyzed samples with three different concentrations of standards.

3.6. Limit of Detection (LOD) and Limit of Quantification (LOQ). The detection limit of an individual analytical procedure is the lowest amount of analyte in the sample which can be detected but not necessarily quantitated as an exact value. The quantitation limit of an individual analytical procedure is the lowest amount of analyte in the sample which can be quantitatively determined with suitable precision and accuracy. The LOD and LOQ of the proposed method were determined by using calibration curve:

$$
\mathrm{LOD}=\frac{3.3 \sigma}{S}, \quad \mathrm{LOQ}=\frac{10 \sigma}{S},
$$

where $\sigma$ is the standard deviation of the response ( $Y$ intercept) and $S$ is the slope of the calibration curve.

3.7. Sandell's Sensitivity. Sandell's sensitivity, the concentration of the analyte (in $\mu \mathrm{g} / \mathrm{mL}$ or $\mu \mathrm{g} / \mathrm{cm}^{2}$ ) which will give an absorbance of 0.001 in a cell of path length $1 \mathrm{~cm}$, was calculated. It gives valuable information regarding sensitivity of the method.

\section{Results and Discussion}

The solutions of $10 \mu \mathrm{g} / \mathrm{mL}$ of both LAM and INH were analyzed and the $\lambda_{\max }$ was found to be $272 \mathrm{~nm}$ and $262 \mathrm{~nm}$, respectively. Three isoabsorptive points: $246 \mathrm{~nm}, 257 \mathrm{~nm}$, and $292 \mathrm{~nm}$ were found in overlaying spectra (Figure 3) and the isoabsorptive point $246 \mathrm{~nm}$ was selected for further analysis.

The calibration curve of LAM and INH individually and the mixture of both drugs at $272 \mathrm{~nm}\left(\lambda_{1}\right)$ and $246 \mathrm{~nm}$ $\left(\lambda_{2}\right)$ were plotted (Figures 4,5 , and 6). The relationship between the absorbance and the concentration of LAM and $\mathrm{INH}$ was found to be linear in the range of $5-30 \mu \mathrm{g} / \mathrm{mL}$ at

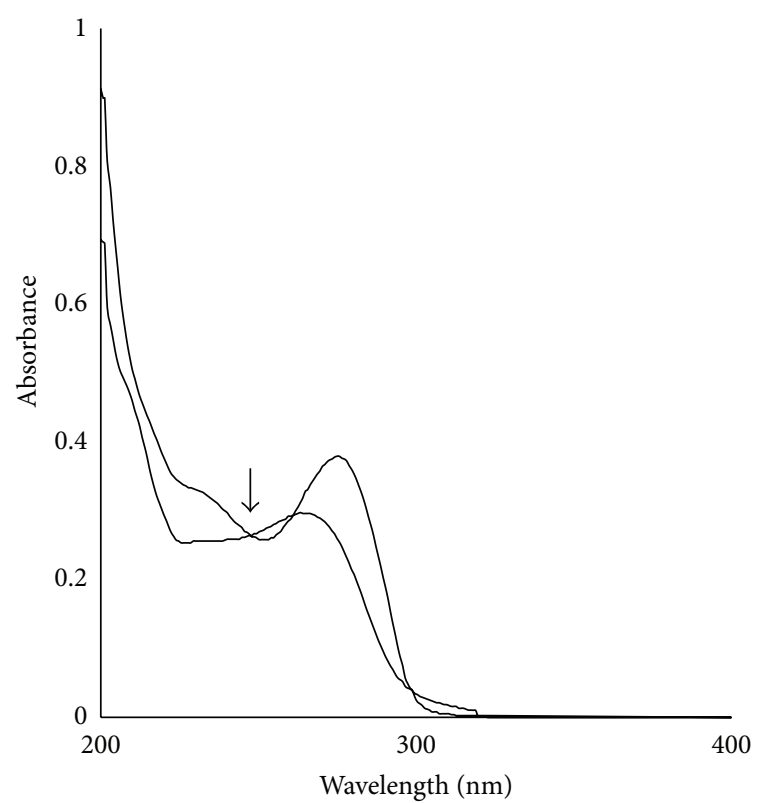

FIGURE 3: UV scan of LAM and INH showing isoabsorptive points.

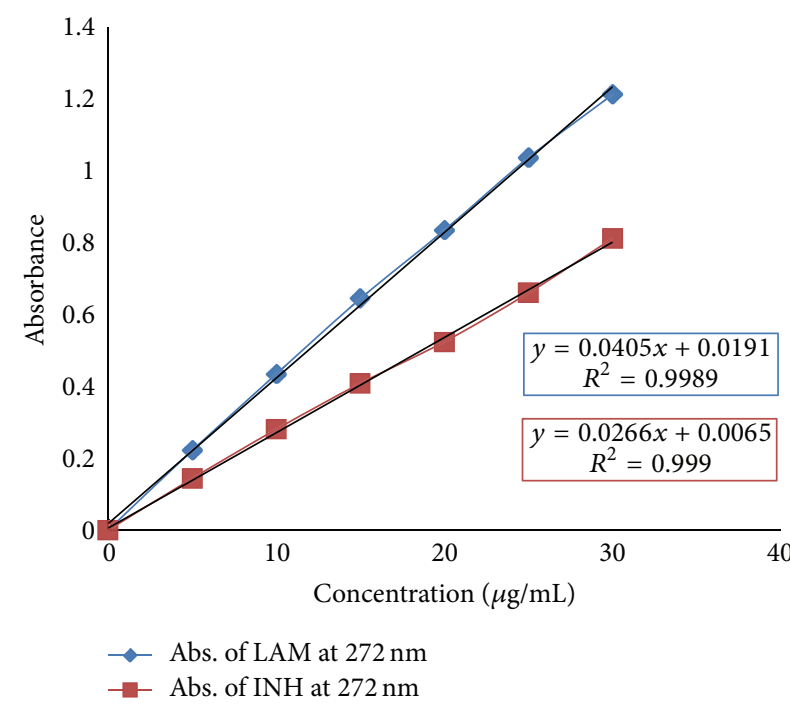

FIGURE 4: Calibration curve of LAM and INH at $272 \mathrm{~nm}$.

both wavelengths $246 \mathrm{~nm}$ and $272 \mathrm{~nm}$. The representative linear equations were calculated by the least squares method and the correlation coefficients have indicated very good linearity (Table 1). Evaluation of repeatability and intermediate precision was done and coefficients of variation (CV) or percent relative standard deviation (\%RSD) values were calculated. These values were found to be less than two $(\mathrm{CV}<$ 2 ), indicating good precision (Table 2). Good accuracy of the proposed method was proved by good percent recovery in standard addition method. It ranged between 99.65 and 101.91\% for LAM and 101.26 and $100.12 \%$ for INH (Table 3).

The limit of detection of LAM and INH at isoabsorptive point $(246 \mathrm{~nm})$ was found to be $0.106 \mu \mathrm{g} / \mathrm{mL}$ and $0.078 \mu \mathrm{g} / \mathrm{mL}$. The LOD at $272 \mathrm{~nm}$ was found to be 
TABLE 1: Calibration points of standard curve with standard deviation (SD) and \%RSD.

\begin{tabular}{|c|c|c|c|c|c|c|c|c|}
\hline \multirow{3}{*}{$\begin{array}{l}\text { Concentration } \\
\text { of the solution } \\
(\mu \mathrm{g} / \mathrm{mL})\end{array}$} & \multicolumn{4}{|c|}{ At $246 \mathrm{~nm}$} & \multicolumn{4}{|c|}{ At $272 \mathrm{~nm}$} \\
\hline & \multicolumn{2}{|c|}{ LAM } & \multicolumn{2}{|c|}{ INH } & \multicolumn{2}{|c|}{ LAM } & \multicolumn{2}{|c|}{ INH } \\
\hline & $\begin{array}{c}\text { Mean } \\
\text { absorbance } \pm \\
\text { SD }(n=3)\end{array}$ & $\% \mathrm{RSD}$ & $\begin{array}{c}\text { Mean } \\
\text { absorbance } \pm \\
\text { SD }(n=3)\end{array}$ & $\% \mathrm{RSD}$ & $\begin{array}{c}\text { Mean } \\
\text { absorbance } \pm \\
\text { SD }(n=3)\end{array}$ & $\%$ RSD & $\begin{array}{c}\text { Mean } \\
\text { absorbance } \pm \\
\text { SD }(n=3)\end{array}$ & $\% \mathrm{RSD}$ \\
\hline 5 & $0.152 \pm 0.0015$ & 1.007159 & $0.149 \pm 0.0020$ & 1.400224 & $0.222 \pm 0.0025$ & 1.132 & $0.144 \pm 0.0026$ & 1.83733 \\
\hline 10 & $0.288 \pm 0.0026$ & 0.918664 & $0.287 \pm 0.0025$ & 0.875851 & $0.435 \pm 0.0026$ & 0.608 & $0.281 \pm 0.0049$ & 1.75756 \\
\hline 15 & $0.429 \pm 0.0040$ & 0.941332 & $0.419 \pm 0.0040$ & 0.965315 & $0.645 \pm 0.0035$ & 0.544 & $0.409 \pm 0.0040$ & 0.98894 \\
\hline 20 & $0.569 \pm 0.0035$ & 0.617565 & $0.538 \pm 0.0036$ & 0.670177 & $0.836 \pm 0.007$ & 0.837 & $0.525 \pm 0.0045$ & 0.85945 \\
\hline 25 & $0.715 \pm 0.0046$ & 0.64092 & $0.687 \pm 0.0057$ & 0.828093 & $1.038 \pm 0.0060$ & 0.581 & $0.661 \pm 0.0065$ & 0.98383 \\
\hline 30 & $0.834 \pm 0.0055$ & 0.660116 & $0.802 \pm 0.0060$ & 0.751273 & $1.214 \pm 0.0095$ & 0.786 & $0.813 \pm 0.0035$ & 0.43214 \\
\hline
\end{tabular}

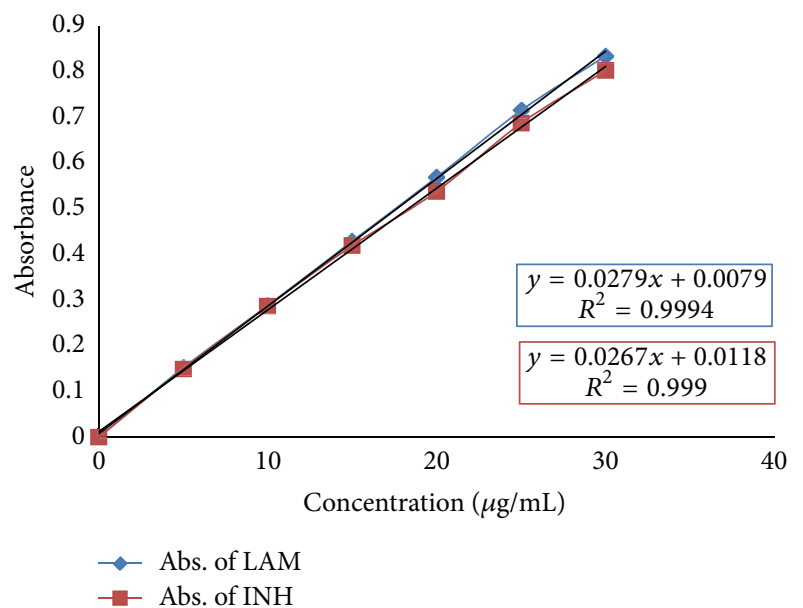

FIGURE 5: Calibration curve of LAM and INH at $246 \mathrm{~nm}$.

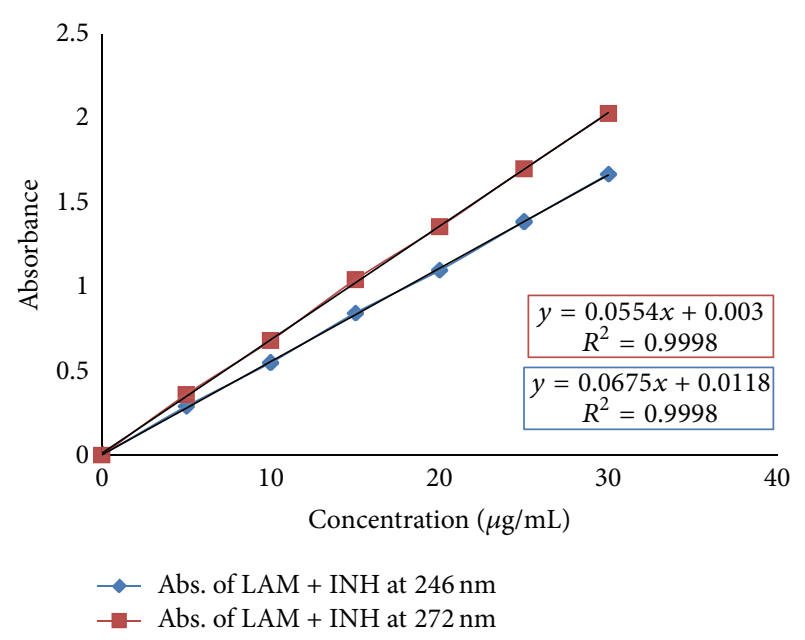

FIGURE 6: Calibration curve of LAM + INH at $272 \mathrm{~nm}$ and $246 \mathrm{~nm}$.

$0.186 \mu \mathrm{g} / \mathrm{mL}$ and $0.211 \mu \mathrm{g} / \mathrm{mL}$ for LAM and $\mathrm{INH}$, respectively. The limit of quantification of LAM and INH at isoabsorptive point $(246 \mathrm{~nm})$ was found to be $0.321 \mu \mathrm{g} / \mathrm{mL}$ and $0.238 \mu \mathrm{g} / \mathrm{mL}$. The LOQ at $272 \mathrm{~nm}$ was found to be
TABLE 2: Intraday and intermediate precision study.

\begin{tabular}{lcccc}
\hline Precision & $\begin{array}{c}\text { \% Estimation } \\
\text { of LAM } \pm \text { SD } \\
(n=6)\end{array}$ & \%RSD & $\begin{array}{c}\text { \% Estimation of } \\
\text { INH } \pm \text { SD } \\
(n=6)\end{array}$ & \%RSD \\
\hline $\begin{array}{l}\text { Intraday } \\
\text { precision }\end{array}$ & $99.88 \pm 0.56$ & 0.562 & $99.92 \pm 0.84$ & 0.844 \\
$\begin{array}{l}\text { Intermediate } \\
\text { precision }\end{array}$ & $99.79 \pm 0.53$ & 0.531 & $99.82 \pm 0.86$ & 0.861 \\
\hline
\end{tabular}

TABLE 3: Results of recovery studies of LAM and INH.

\begin{tabular}{ccccc}
\hline Drug & $\begin{array}{c}\text { Amount } \\
\text { taken } \\
(\mu \mathrm{g} / \mathrm{mL})\end{array}$ & $\begin{array}{c}\text { Amount } \\
\text { added } \\
(\mu \mathrm{g} / \mathrm{mL})\end{array}$ & $\begin{array}{c}\text { Amount } \\
\text { found } \\
(\mu \mathrm{g} / \mathrm{mL})\end{array}$ & $\begin{array}{c}\text { \% Recovery } \pm \\
\text { SD }(n=3)\end{array}$ \\
\hline \multirow{3}{*}{$\mathrm{INH}$} & 10 & 1 & 11.14 & $101.26 \pm 0.40$ \\
& 10 & 2 & 12.02 & $100.17 \pm 0.87$ \\
& 10 & 3 & 13.02 & $100.12 \pm 0.98$ \\
\hline \multirow{2}{*}{$\mathrm{LAM}$} & 15 & 1 & 16.31 & $101.91 \pm 0.68$ \\
& 15 & 2 & 17.15 & $100.90 \pm 0.57$ \\
& 15 & 3 & 17.93 & $99.65 \pm 1.23$ \\
\hline
\end{tabular}

$0.563 \mu \mathrm{g} / \mathrm{mL}$ and $0.639 \mu \mathrm{g} / \mathrm{mL}$ for LAM and $\mathrm{INH}$, respectively. Sandell's sensitivity of LAM and INH at $246 \mathrm{~nm}$ was found to be 0.0347 and $0.0348 \mu \mathrm{g} / \mathrm{cm}^{2}$. At $272 \mathrm{~nm}$ it was 0.0229 and $0.0356 \mu \mathrm{g} / \mathrm{cm}^{2}$ for LAM and INH, respectively, which indicates good sensitivity of the method. Various validation parameters have been summarized in Table 4 .

\section{Conclusion}

The UV spectrophotometric Q-absorption ratio method was developed and validated for the simultaneous analysis of LAM and INH. The results together established that the method is simple, accurate, precise, reproducible, rapid, and sensitive. The method could be applied successfully and economically for the simultaneous estimation of LAM and INH in laboratory samples for efficient data generation and for combination formulations of these two drugs in the future. 
TABLE 4: Summary of regression characteristics and validation parameters.

\begin{tabular}{lcccc}
\hline \multirow{2}{*}{ Parameters } & \multicolumn{2}{c}{ LAM } & \multicolumn{2}{c}{ INH } \\
& $246 \mathrm{~nm}$ & $272 \mathrm{~nm}$ & $246 \mathrm{~nm}$ & $272 \mathrm{~nm}$ \\
\hline $\begin{array}{l}\text { Beer's law limit } \\
(\mu \mathrm{g} / \mathrm{mL})\end{array}$ & $5-30$ & $5-30$ & $5-30$ & $5-30$ \\
$\begin{array}{l}\text { Absorptivity } \\
\text { Regression equation } \\
(y=m x+c)\end{array}$ & 287 & 435 & 288 & 276 \\
$\quad$ & & & & \\
$\quad$ Slope $(m)$ & 0.0279 & 0.0405 & 0.0267 & 0.0266 \\
$\quad$ Intercept $(c)$ & 0.0079 & 0.0191 & 0.0118 & 0.0065 \\
$\begin{array}{l}\text { Correlation coefficient } \\
\left(r^{2}\right)\end{array}$ & 0.9994 & 0.9989 & 0.999 & 0.999 \\
$\begin{array}{l}\text { Standard deviation } \\
(\text { SD })\end{array}$ & 0.0009 & 0.0023 & 0.0006 & 0.0017 \\
$\begin{array}{l}\text { LOD }(\mu \mathrm{g} / \mathrm{mL}) \\
\text { LOQ }(\mu \mathrm{g} / \mathrm{mL})\end{array}$ & 0.106 & 0.186 & 0.078 & 0.211 \\
$\begin{array}{l}\text { Sandell's sensitivity } \\
\left(\mu \mathrm{g} / \mathrm{cm}^{2}\right)\end{array}$ & 0.321 & 0.563 & 0.238 & 0.639 \\
\hline
\end{tabular}

\section{Conflict of Interests}

The authors declare that there is no conflict of interests regarding the publication of this paper.

\section{Acknowledgments}

The authors are thankful to Mylan Laboratories, Nashik, Maharashtra, India, and Lupin Pharma Ltd., Pune, Maharashtra, India, for providing gift samples of pure drug lamivudine and isoniazid, respectively, and Department of Pharmaceutics, Indian Institute of Technology (Banaras Hindu University), Varanasi, UP, for research support.

\section{References}

[1] http://apps.who.int/iris/bitstream/10665/75938/1/97892415645 02_eng.pdf.

[2] Global Aids Response Progress Reporting, UNAIDS, Geneva, Switzerland, 2012.

[3] D. Aerts and R. Jobim, "The epidemiological profile of tuberculosis in southern Brazil in times of AIDS," International Journal of Tuberculosis and Lung Disease, vol. 8, no. 6, pp. 785-791, 2004.

[4] United States Pharmacopoeia 30/National Formulary 25, United States Pharmacopoeial Convention, Rockville, Md, USA, 2007.

[5] K. D. Tripathi, Essentials of Medical Pharmacology, Jaypee Brothers Medical, New Delhi, India, 6th edition, 2009.

[6] L. L. Brunton, J. S. Lazo, and K. L. Parker, Goodman and Gilman's the Pharmacological Basis of Therapeutics, McGraw Hill, New York, NY, USA, 11th edition, 2006.

[7] A. H. Beckett and J. B. Stenlake, Practical Pharmaceutical Chemistry-Part Two, CBS, New Delhi, India, 4th edition, 2005.

[8] R. C. Hirt, F. T. King, and R. G. Schmitt, "Graphical absorbanceratio method for rapid two-component spectrophotometric analysis," Analytical Chemistry, vol. 26, no. 8, pp. 1270-1273, 1954.
[9] G. Singh, D. Kumar, D. Sharma, M. Singh, and S. Kaur, "QAbsorbance ratio spectrophotometric method for the simultaneous estimation of prednisolone and 5-Amino salicylic acid in tablet dosage form," Journal of Applied Pharmaceutical Science, vol. 2, no. 6, pp. 222-226, 2012.

[10] A. B. Chaudhary, R. K. Patel, S. A. Chaudhary, and K. V. Gadhvi, "Estimation of valsartan and hydrochlorothiazide in pharmaceutical dosage forms by absorption ratio method," International Journal of Applied Biology and Pharmaceutical Technology, vol. 1, no. 2, pp. 455-464, 2010.

[11] P. C. Bhamare, S. B. Bari, S. Natarajan, A. A. Patil, S. H. Patil, and P. T. Shirode, "A new analytical method development and validation of metformin hydrochloride and fenofibrate by absorbance ratio UV spectrophotometric method," Asian Journal of Biochemical and Pharmaceutical Research, vol. 1, no. 2, pp. 115-128, 2011.

[12] ICH, "Q2A, Validation of analytical methods: definition and terminology," 1994.

[13] Validation of Analytical Procedures: Text and Methodology Q2 (R1), ICH Harmonised Tripartite Guideline, London, UK, 2005.

[14] ISO-VIM, International Vocabulary of Basic and General Terms in Metrology, International Organisation for Standardization, 2004. 

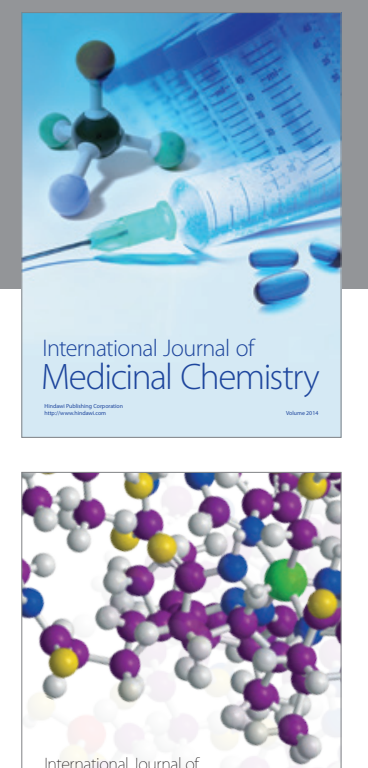

\section{Carbohydrate} Chemistry

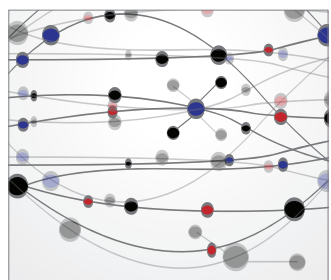

The Scientific World Journal
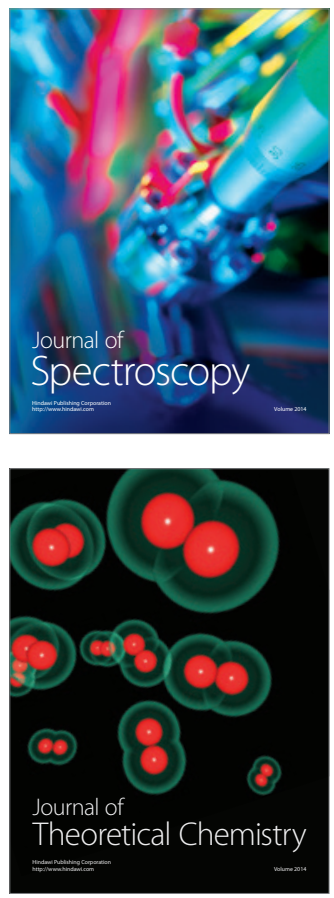
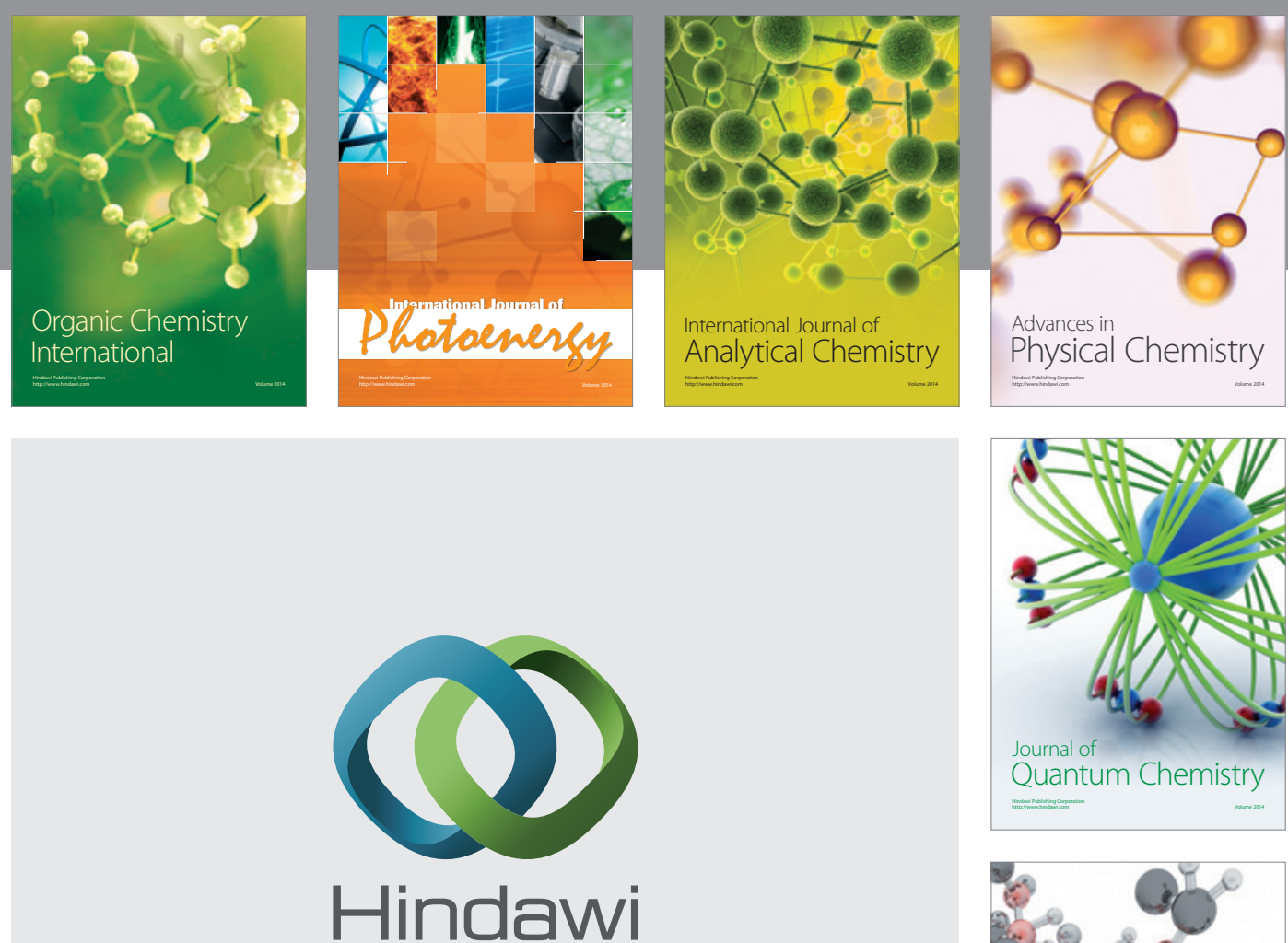

Submit your manuscripts at

http://www.hindawi.com

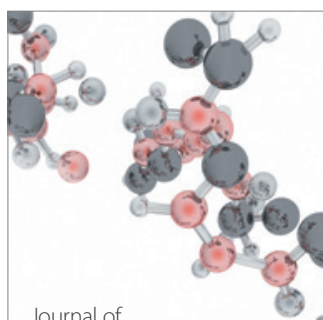

Analytical Methods

in Chemistry

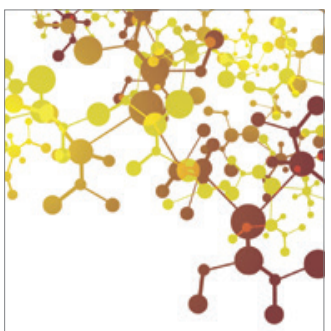

Journal of

Applied Chemistry

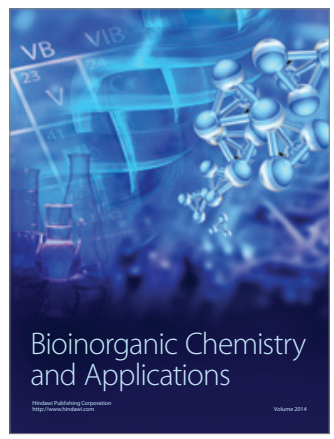

Inorganic Chemistry
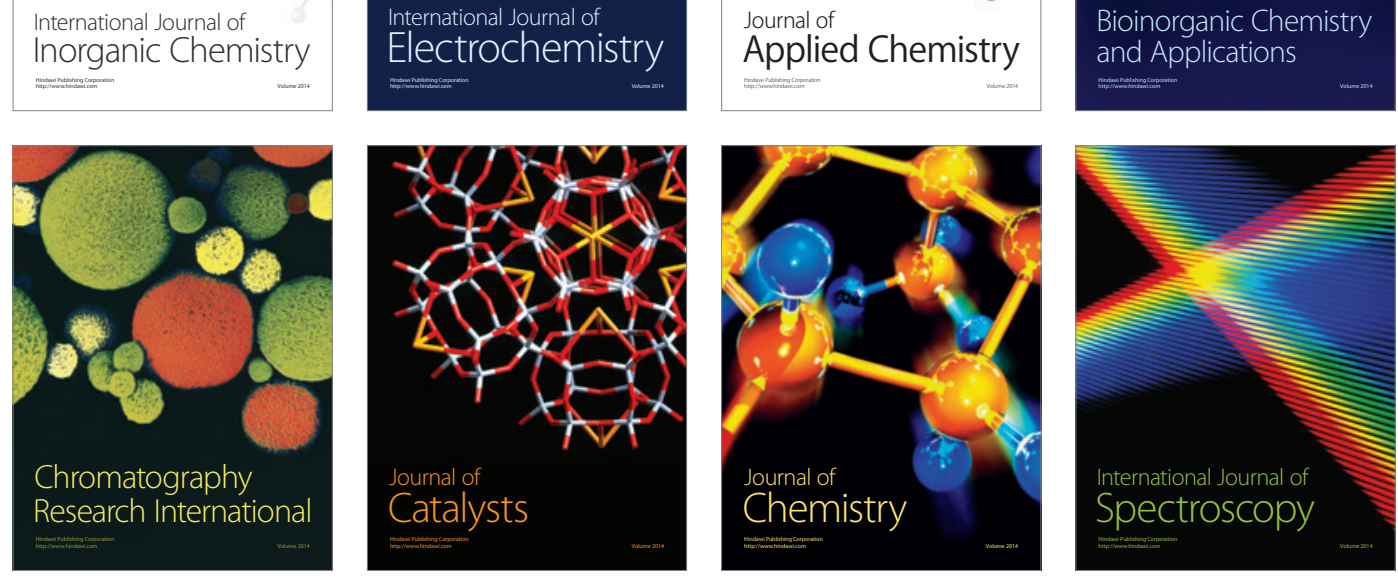